\title{
Erratum
}

Cold Spring Harb Protoc 2014; doi: 10.1101/pdb.prot080721

\section{Erratum: Electrophoretic Mobility Shift Assays for RNA-Protein Complexes}

Donald C. Rio

Due to a typesetter error, the volumes of Tris base and glycine in the recipe entitled "Tris-Glycine Buffer $(10 \times)$ " were incorrect when this article was first published. The publisher apologizes for this error. A corrected version of the recipe is given below. In addition, the current version of the article and the HTML version of the recipe (doi:10.1101/pdb.rec082206) have been amended accordingly.

Tris-Glycine Buffer (10×)

\begin{tabular}{lcc} 
Reagent & Quantity (for 1 L) & Final concentration \\
\hline Tris base $(1 \mathrm{M})$ & $500 \mathrm{~mL}$ & $0.5 \mathrm{M}$ \\
Glycine $(1 \mathrm{M})$ & $500 \mathrm{~mL}$ & $0.5 \mathrm{M}$
\end{tabular}

Store at $4^{\circ} \mathrm{C}$. The $\mathrm{pH}$ should be $\sim 8.8$. 


\section{Erratum: Electrophoretic Mobility Shift Assays for RNA-Protein Complexes}

Donald C. Rio

Cold Spring Harb Protoc; doi: 10.1101/pdb.err106104

\begin{aligned} & \hline $\begin{array}{r}\text { Email Alerting } \\ \text { Service }\end{array}$ Receive free email alerts when new articles cite this article - click here. \\ & \hline $\begin{array}{c}\text { Subject } \\ \text { Categories }\end{array}$ Browse articles on similar topics from Cold Spring Harbor Protocols. \\ & \hline\end{aligned}

